\title{
Topics In Finance Part II - Financial Analysis
}

\author{
Judy Laux, Colorado College, USA
}

\begin{abstract}
The second article in a series designed to supplement the introductory financial management course, this essay addresses financial statement analysis, including its impact on stock valuation, disclosure, and managerial behavior.
\end{abstract}

Keywords: financial analysis, financial management, stockholder wealth maximization, agency theory

\section{INTRODUCTION}

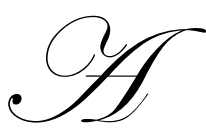

s students embark upon their journey through the first managerial finance course, they too often focus on the mechanical aspects of the course and fail to absorb the essential theoretical concepts intended to guide those mechanics. This "missing the forest for the trees" dilemma rings especially true when approaching the topic of financial analysis. Tempted to memorize the ratios for exams, students overlook the fact that stockholder wealth maximization (SWM), the risk-return relationship, and agency theory are inextricably linked to financial analysis. Those topics, which formed the basis for part one of this series [Laux, forthcoming], will be revisited here as they relate to financial analysis. In a nutshell, SWM-assumed as the goal of financial managers ${ }^{1}$ - is a function of long-term stock price, and the stock price depends to a great extent on financial reports. Analysts employ ratio analysis in arriving at their buy/hold/sell recommendations, and managers consider the effects of accounting choice and use disclosure as a method of supplementing required financial reporting, often with agency ramifications. First, the current article reviews financial analysis and couples it with the conceptual challenges for managers (including potential agency conflicts). This coverage is followed by a section devoted to the conceptual and empirical literature related to financial analysis, including disclosure.

\section{FINANCIAL ANALYSIS AND MANAGERIAL BEHAVIOR}

Textbook presentations of financial analysis devote the bulk of this introduction to the ratios commonly generated to judge firm performance, categorizing them as profitability, asset utilization (or "activity"), liquidity, and debt utilization (or "leverage") ratios. You might choose to briefly review that material, but the purpose here is to look at the ratios from the perspectives of stockholder welfare, the risk-return relationship, and managerial behavior (or potential misbehavior) as respects agency theory.

In investigating a firm's ability to earn an acceptable return on sales, assets, and equity, analysts look to the profitability ratios, all of which depend on reported net income from the income statement and, for the assets and equity, reported measures from the balance sheet. Of course, sales have a direct impact on reported net income. For these measures, typically managers are expected to do most of the following:

- Generate increasing levels of both sales and net income, preferably combined with an increasing percentage of net income to sales (indicating an upward trajectory of cost containment-lower expenses per dollar of sales);

- $\quad$ Generate progressively higher income per dollar invested in assets;

- Generate progressively higher income per dollar of equity.

\footnotetext{
${ }^{1}$ See Laux [forthcoming] for the pros and cons of this assumption as outlined in the literature.
} 
In the DuPont version of return on equity (which breaks the calculation into profit margin, asset turnover, and a leverage component), managers would also be asked to generate more dollars of sales per dollar invested in assets and be applauded for incorporating a healthy use of leverage to magnify returns to stockholders. Thus one of the asset utilization ratios, total asset turnover (Sales/Total Assets) and a debt utilization measure provide further analysis of the causal factors of return on equity. Seems simple enough, right? But financial managers face a number of challenges linked to SWM, risk and return, and the principal-agent relationship. Let's review just a few.

For the profit margin (Net Income/Sales), as noted above, managers are to raise both net income and sales, preferably with net income increasing at a faster rate than sales. Prices are based, in large part, on expectations about such things as sales and net income. When firms fall short of the sales or net income forecasts of analysts, the market price of the stock typically suffers. Thus, in an effort to maximize shareholder wealth as reflected in the stock price, managers attempt to ensure that expectations are met. Often they do so by smoothing sales and income so that, over time, projections are easier to make, risk is lowered, and the stock price is maximized. (This is an example of the "maximize return per unit of risk" directive referenced in part one of this series.) Sometimes this smoothing activity leads to questionable practices, such as moving expected sales forward (with special contractual arrangements with customers) in years in which sales are falling short, or postponing deliveries and sales recognition in years when sales are above expectations. Of course, the result is a distortion of economic reality (and, occasionally, a breach of accounting standards). Likewise, to contain expenses in a year in which income is falling short of expectations, managers can postpone needed maintenance, training sessions, or research and development expendituresdiscretionary expenses that might be imperative for long-run success. The result here is to sacrifice long-term wealth in favor of short-term stock price maintenance. As you can see SWM, risk and return, and agency conflicts play critical roles in the area of financial analysis. And we have only covered a single ratio! To abbreviate this discussion, following is a summary of the financial ratios, including the expectations placed on managers, the relationship of the ratios to stockholder wealth maximization and risk and return, possible managerial reactions, and some potential agency conflicts.

\section{Profitability Ratios}

Profit Margin = Net Income/Sales

- $\quad$ Analyst expectations: Increase net income and sales as well as the net income as a percentage of sales.

- Relationship to SWM: The market price of the stock is related to future cash flows, which depend on sales and earnings. Steady sales and net income reduce risk and raise prices.

- Potential problems and complexities: Sales and net income are difficult to "control." Much of the economic decision making is in the hands of customers and suppliers.

- Possible managerial reactions: Accounting flexibility, especially in the timing of reporting revenues and expenses, can be used to smooth sales and earnings. Managers can postpone (unwisely) discretionary expenditures. "Within-GAAP" reporting can become fraudulent reporting, wherein economic reality is not reflected in the financial statement information.

\section{Return on Assets $=$ Net Income/Total Assets}

- Analyst expectations: Increase net income per dollar invested in assets; reduce the asset base needed to generate net income.

- $\quad$ Relationship to SWM: A firm's ability to generate more income per dollar of assets implies higher efficiency and drives up stock prices.

- $\quad$ Potential problems and complexities: The asset base required to generate net income is typically measured at "book value" (original cost less accumulated depreciation) and can vary with (1) the age of the firm and its assets, (2) the depreciation method used, (3) asset revaluation (write-downs), and (4) inflation.

- $\quad$ Possible managerial reactions: To reduce the book value of the asset base, managers can use accelerated depreciation methods and understate the expected salvage value. The first might violate the "matching" of revenues and expenses, while the latter accelerates the expense and postpones a gain on sale. The choice of depreciation method is within GAAP, but managers can run into agency problems when they change accounting methods to disguise economic reality. Managers might write down assets in a bad year to, in 
effect, get all the bad news out to investors at once (called "big bath" accounting). This reduces asset values, lowers future depreciation expense, magnifies future returns, and distorts economic reality.

Return on Equity = Net Income/Stockholders' Equity

- $\quad$ Analyst expectations: Increase net income per dollar invested by the owners.

- $\quad$ Relationship to SWM: A firm's ability to generate more income per dollar invested by the owners is viewed positively in the marketplace. However, it can come about either by effective asset utilization (discussed below) or the use of leverage (more dollars of assets provided by creditors).

- $\quad$ Potential problems and complexities: While leverage can magnify returns to stockholders, it also magnifies risk (the risk of default), and overuse can reduce the stock price. Stockholders' equity is a book value measure and can differ drastically for old versus new firms, making comparability problematic.

- Possible managerial reactions: Managers can be tempted to "play games" with stockholders' equity, repurchasing stock or using other activities that affect retained earnings (and therefore stockholders' equity). If managers employ accounting games to manipulate either net income or stockholders' equity to buoy up current stock prices, this might not be in the long-term best interests of the stockholders.

\section{Asset Utilization Ratios}

Receivables Turnover $=$ Sales/Accounts Receivable

- Analyst expectations: Maximize sales per dollar invested in accounts receivable. Collect accounts receivable quickly, lowering the average outstanding balance and days in the collection period.

- Relationship to SWM: Dollars wrapped up in accounts receivable are generating no return, and the risk of non-collection rises as days in the collection period rise.

- $\quad$ Potential problems and complexities: Harsh collection tactics can cause a firm to lose customers, and exceptionally tight credit standards can reduce sales. Loose standards can lead to uncollectible accounts.

- Possible managerial reactions: Managers are sometimes tempted to understate estimated uncollectible accounts (to reduce bad debts expense), although this also increases the receivables balance, decreasing the turnover ratio. In addition, they might fail to update credit standards as economic conditions change. Most importantly, managers must constantly fight the temptation to overstate sales (or make sales on credit that will not be collected).

Inventory Turnover $=$ Sales/Inventory (or Cost of Goods Sold/Inventory)

- $\quad$ Analyst expectations: Maximize goods sold (as measured either at retail or cost) per dollar invested in inventory. Minimize the time goods set on the shelf (minimize average dollars in inventory).

- $\quad$ Relationship to SWM: Dollars wrapped up in inventory generate no return (and generally have high associated costs). The risk of obsolescence, damage, or theft rises with time on the shelves.

- Potential problems and complexities: Inventory costing methods differ (LIFO versus FIFO, for example), causing potential problems with comparability. Harsh sales tactics can cause customers to buy products they later return (or fail to pay for), and keeping inventory too low can lead to stock outs.

- $\quad$ Possible managerial reactions: Managers are sometimes tempted to use inventory valuation choices to disguise fundamental economic problems, and problems similar to those mentioned for receivables turnover apply here.

Asset Turnover $=$ Sales/Total Assets

- $\quad$ Analyst expectations: Increase sales per dollar invested in assets.

- $\quad$ Relationship to SWM: A firm's ability to generate more sales per dollar of assets implies higher efficiency and drives up stock prices.

- Potential problems and complexities: The asset base required to generate sales is measured at book value (See previous discussion of this dilemma.).

- $\quad$ Possible managerial reactions: See "Return on Assets." 


\section{Liquidity Ratios}

\section{Current Ratio $=$ Current Assets/Current Liabilities}

- Analyst expectations: The higher this ratio, the better able a company should be to pay its bills on time.

- $\quad$ Relationship to SWM: A higher ratio indicates greater liquidity, lower risk, and higher stock price.

- Potential problems and complexities: If too much of the current assets are in inventory and prepaid expenses, a firm might be at risk, since debts must be paid in cash.

- $\quad$ Possible managerial reactions: Problems already noted for measuring and controlling both accounts receivable and inventory apply here as well.

Quick Ratio $=$ Current Assets less Inventory less Prepaid Expenses/Current Liabilities

- Analyst expectations: The higher this ratio, the better able a firm is to pay its bills on time. This is a more stringent test than the current ratio, because the less liquid (riskier) assets are removed from the numerator.

- Relationship to SWM: The existence of short-term liabilities is riskier than long-term debt because they must be paid back sooner (increasing the risk of default). However, short-term debt is usually cheaper (especially free trade credit in the form of accounts payable), driving up return.

- Potential problems and complexities: This ratio eliminates some of the problems associated with the current ratio. Still, perfect matching of cash inflows and debt repayment can be challenging.

- $\quad$ Possible managerial reactions: Managers may take advantage of the free credit extended by suppliers; if the firm delays payments unduly, this could damage supplier relationships, ultimately undermining the long-term wealth of the firm and its stockholders.

\section{Debt Utilization Ratios}

Debt to Assets Ratio $=$ Total Liabilities/Total Assets

- $\quad$ Analyst expectations: This percentage, representing the amount of debt per dollar of assets, is typically compared with industry norms to determine acceptability.

- Relationship to SWM: The higher this ratio, the more leverage and the greater risk. The potential return lies in the firm's ability to generate higher returns on the portion provided by creditors than the cost of this debt.

- $\quad$ Potential problems and complexities: The liability value may be close to a true market value (the amount required to eliminate the debt), while the asset base is at book value (See previous discussion.). Thus a newer firm with essentially the same physical asset base might show a lower debt ratio than an older firm with depreciated asset values.

- Possible managerial reactions: Financial managers must judge whether the relative amount of debt is judicious and will time debt issuance to occur during favorable markets for debt. Equity issuance typically dampens earnings per share and stock prices, so managers sometimes tend to avoid such issuance. In addition, managers have been known to participate in "off-balance sheet financing" in which they construct lease agreements to avoid classifying them as capital leases (showing both an asset and a liability on the balance sheet); the result is an understated debt-to-assets ratio that does not reflect economic reality. Other risk-taking/risk-avoidance behaviors are discussed in later articles on leverage and capital structure.

Times Interest Earned $=$ Operating Income*/Interest Expense (*Income before interest and taxes)

Fixed Charge Coverage Ratio $=$ Operating Income + Lease Payments/Fixed Charges (including interest and leases)

- Analyst expectations: The higher the coverage numbers the better for investors. They indicate the number of times operating income could pay interest expense and total fixed charges.

- Relationship to SWM: Higher numbers indicate less risk of defaulting on interest payments to creditors and required payments to leaseholders, and this is valued positively by the market. 
- Potential problems and complexities: If a company is generating high profits but low cash flows from operations, these numbers can be misleading, not reflective of economic reality; interest and lease requirements can only be paid with cash.

- Possible managerial reactions: Any actions that artificially inflate operating income will also overstate the interest and fixed charge coverage ratios.

\section{Market-Based Ratios}

Earnings per Share $=$ Net Income less Preferred Dividends/Average number of Common Shares Outstanding

- $\quad$ Analyst expectations: Perhaps the most influential measure for setting stock prices, the EPS is expected to meet expectations; investors want it to be high and to grow over time.

- $\quad$ Relationship to SWM: A smooth, upward trajectory for EPS reduces risk and increases share price. Managers focus (perhaps too much) on making this happen.

- $\quad$ Potential problems and complexities: Any cautions previously noted about net income and earnings manipulation apply here. Also, treasury stock transactions affect the number of shares outstanding.

- Possible managerial reactions: Because meeting EPS expectations is considered so paramount to maximizing the stock price, managers are tempted to smooth income, engage in treasury stock transactions, and employ voluntary disclosure (to influence analyst expectations) to make this a reality.

\section{Price-Earnings Ratio $=$ Market Price per Share/EPS}

- $\quad$ Analyst expectations: The "multiple" the market places on a firm's earnings, this ratio reflects investor optimism about the firm's future; the higher, the more optimistic investors are about the firm's ability to generate earnings into the future.

- $\quad$ Relationship to SWM: If investors are optimistic about the firm's future earnings prospects, this ratio will be higher than the industry average. If it grows over time, this indicates the market's enthusiasm for managerial actions.

- Potential problems and complexities: If the EPS are falling, this ratio can become inflated and not represent true optimism about the firm's prospects.

- $\quad$ Possible managerial reactions: The tactics associated with meeting EPS expectations apply here.

Dividend Yield $=$ Dividends per Share/Market Price per Share

- Analyst expectations: For dividend-paying companies, investors want to see this number high and growing, because it is a measure of return on invested dollars.

- $\quad$ Relationship to SWM: One of the two returns associated with stock ownership (the other being stock price appreciation), dividends represent a cash flow that helps determine the stock price. The steadier this cash flow over time, the better, because risk is reduced, expected return is reduced, and the stock price rises.

- $\quad$ Potential problems and complexities: Not all investors want dividend income; some prefer market price appreciation. Theory suggests investors should seek out firms that align with their interests. Also, in theory, managers should reinvest income in all positive net present value projects, paying dividends only when they cannot find acceptable projects.

- $\quad$ Possible managerial reactions: Sometimes managers will retain earnings even when they lack sufficiently profitable projects (those that return greater than the weighted average cost of capital). While this might buoy up current income, it destroys long-term wealth.

Note that this analysis is abbreviated, and the articles to follow in this series will elaborate on these items. For now, this offers a simple overview linking financial analysis with SWM, risk and return, and managerial behavior. For an enjoyable pre-Sarbanes-Oxley review of financial analysis, Understanding the Corporate Annual Report: Nuts, Bolts and a Few Loose Screws [2003] is a must read. It offers a succinct summary of financial statements and ratios while pointing out the red flags that might help analysts detect earnings manipulation and fraudulent reporting. For the financial manager, it might offer a financial statement user's perspective on what's confusing, what's 
enlightening, and what's so darned irritating about financial managers' attempts to magnify the good and downplay (or even hide) the bad. Textbooks present financial analysis from the perspective of the financial manager whose objectives are to outperform the competition and attract capital to the firm. The next section introduces some of the research associated with financial analysis and corporate disclosure.

\section{FINANCIAL ANALYSIS IN THE LITERATURE}

The literature on financial analysis addresses two primary questions: (1) How does the analysis of information in financial statements influence stock prices? (2) How does disclosure affect users' decisions? The research on these questions is massive, and the current article will touch on some of the most widely cited and on some of the more contemporary articles.

On the question of relevance to stock prices, Francis and Schipper [1999] show that earnings relevance has decreased over time, but certain balance sheet information (specifically, the book value of asset and liabilities) has shown little degradation. Kim and Kross [2005] find that the ability of earnings to predict operating cash flows (rather than stock prices) has increased over time. Cooper et al. [2005] contend that common investing mechanisms that rely on financial statement information do not predict future returns well, ex ante. Barber et al. [2001] also find that, after transactions costs, no profit can be made from investing based on analysts' recommendations. On the contrary, several studies find effectiveness in models founded on financial statement analysis, including Hirshleifer et al. [2004] who discover predictive value in net operating assets (a negative relationship with future stock returns). Similarly, Mohanram [2005] separates winners from losers among low book-to-market value firms using a self-designed "GSCORE" that relies on financial analysis. This article (on pp. 135-137) also offers a superb and brief review of the literature devoted to the book-to-market effect and fundamental analysis, which relies heavily on financial statement information. Piotroski [2000] uses historical financial information to generate an investing strategy to buy winners and short losers among high book-to-market firms. His "composite score" is a function of nine variables - four related to profitability, three to leverage and liquidity, and two to operating efficiency. Nissim and Penman [2001] use financial ratios related to operating activities (profitability) and financing activities (growth) to predict future equity payoff. Several studies concentrate on the usefulness of one popular ratio, the price-earnings (P/E) ratio, in predicting future prices. Both Bhargava and Malhatra [2006] and Jones [2008] find that the P/E ratio fails as a good predictor of future prices; the latter study finds that earnings growth is important, however. Thus, this brief review of literature offers the financial manager some insight into what information "cues" are read and acted upon in the market by investors.

Healy and Palepu [2001] offer the single most comprehensive review of the empirical disclosure literature, dividing the coverage into four areas: Regulation of disclosure (Summary: "regulated financial reports provide new and relevant information to investors," p. 413); auditing and disclosure (Summary: there is not much research on whether auditors "enhance the credibility of financial statements," p. 415); managers' disclosure decisions (Summary: "evidence indicates that financial analysts add value in the capital market...[but] there is also evidence of analyst bias," pp. 416 and 417); capital market consequences of disclosure (Summary: voluntary disclosure theories and evidence vary, and many measurement problems exist, p. 429). In short, this article captures the essence of the empirical studies and categorizes the literature in a meaningful way.

Questions surrounding disclosure have led to a number of articles, some related to the voluntary disclosure of good news versus bad, and others looking more generally at whether investors find disclosure helpful. Skinner [1994] hypothesizes that bad news will be disclosed on a quarterly basis (both to defuse possible litigation and to preserve reputation) but that good news will correspond to annual earnings announcements. In Lang and Lundholm's 1996 study, "Corporate Disclosure Policy and Analyst Behavior," the authors discover that disclosure increases analyst coverage, generates better forecasts, and decreases both dispersion and volatility in forecasts. Similarly, the much cited "Bringing the Future Forward: The Effect of Disclosure on the Returns-Earnings Relation," [Lundholm and Myers, 2002] suggests that "increased disclosure activity 'brings the future forward' into current stock returns..." (p. 810). The authors speculate that disclosure is "filling the gap" created by accounting earnings information that falters in the information economy. The worth of CEO/CFO certification of financial statements is investigated in Chang et al. [2006, p. 1] with two findings: "the certification provides assurance to investors by making disclosure more credible and by reducing information asymmetry between owners and management, and [this] is reflected in the 
stock price of the certifying company." Finally, Gelb and Zarowin [2002] contend that "greater disclosure is associated with stock prices that are more informative about future earnings [and thus] greater disclosure provides information benefits to investors" (p. 33). This research suggests that the investing public appreciates and responds to information disclosure that goes beyond that provided by traditional accounting reports. This is important to financial managers who must weigh the cost of providing such information against the potential benefit gained. Disclosure also bears risk - the risk of misinterpretation, for example. In addition, the information aspect becomes a new competitive item for financial managers; those who fall short of their competitors in the area of disclosure will also fall short of stockholder wealth maximization.

\section{This Series Continues}

As this article has shown, stockholder wealth maximization, risk and return, and the market's response to financial information (including the implications for future cash flows) influence the behavior of the financial manager. The next article investigates the use of various types of leverage, again concentrating on the connections to stockholder welfare, risk and return, and managerial behavior.

\section{AUTHOR INFORMATION}

Judy Laux is a Gerald L. Schlessman Professor of Economics and Business at Colorado College. Her research interests include finance and accounting pedagogy and market efficiency.

\section{REFERENCES}

1. Barber, Brad; Reuven Lehavy; Maureen McNichols, and Brett Trueman. 2001. "Can Investors Profit from the Prophets? Security Analyst Recommendations and Stock Returns." The Journal of Finance, Vol. LVI, No. 2: 531-563.

2. Bhargava, Vivek and D.K. Malhatra. 2006. “Do Price-Earnings Ratios Drive Stock Values?" The Journal of Portfolio Management, Fall issue: 86-92.

3. Cooper, Michael; Roberto C. Gutierrezz, Jr., and Bill Marcum. 2005. "On the Predictability of Stock Returns in Real Time." Journal of Business, Vol. 78, No. 2: 469-499.

4. Chang, Hsihui; Jengfang Chen; Woody M. Liao, and Birendra K. Mishra. 2006. “CEOs'/CFOs' Swearing by the Numbers: Does It Impact Share Price of the Firm?" The Accounting Review, Vol. 81, No. 1: $1-27$.

5. Francis, Jennifer and Katherine Schipper. 1999. "Have Financial Statements Lost Their Relevance?" Journal of Accounting Research, Vol. 37, No. 2: 319-352.

6. Fraser, Lyn M. and Aileen Ormistron. 2003. Understanding the Corporate Annual Report: Nuts, Bolts, and a Few Loose Screws. Upper Saddle River, New Jersey: Prentice-Hall.

7. Gelb, David S. and Paul Zarowin. 2002. "Corporate Disclosure Policy and the Informativeness of Stock Prices."Review of Accounting Studies, Vol. 7: 33-52.

8. Healy and Palepu. 2001. "Information Asymmetry, Corporate Disclosure, and the Capital Markets: A Review of the Empirical Disclosure Literature.” Journal of Accounting and Economics, Vol. 31: 405-440.

9. Hirshleifer, David; Kewei Hour; Siew Hong Teoh, and Yinglei Zhang. 2004. "Do Investors Overvalue Firms With Bloated Balance Sheets?” Journal of Accounting and Economics, Vol. 38: 297-331.

10. Jones, Charles P. 2008. "How Important is the P/E Ratio in Determining Market Returns?" The Journal of Investing, Summer issue: 7-14.

11. Kim, Myungsun and William Kross. 2005. "The Ability of Earnings to Predict Future Operating Cash Flows Has Been Increasing - Not Decreasing.” Journal of Accounting Research, Vol. 43, No. 5: 753-780.

12. Lang, Mark H. and Russell J. Lundholm. 1996. "Corporate Disclosure Policy and Analyst Behavior." The Accounting Review, Vol. 71, No. 4: 467-492.

13. Laux, Judith A. "Topics in Finance: Part I-Introduction and Stockholder Wealth Maximization." American Journal of Business Education, forthcoming.

14. Lundholm, Russell and Linda A. Myers. 2002. "Bringing the Future Forward: The Effect of Disclosure on the Returns-Earnings Relation.” Journal of Accounting Research, Vol. 40, No. 3: 809-839. 
15. Mohanram, Partha S. 2005. "Separating Winners from Losers among Low Book-to-Market Stocks Using Financial Statement Analysis." Review of Accounting Studies, Vol. 10: 133-170.

16. Nissim, Doron and Stephen H. Penman. 2001. "Ratio Analysis and Equity Valuation: From Research to Practice." Review of Accounting Studies, Vol. 4: 109-154.

17. Piotroski, Joseph D. 2000. "Value Investing: The Use of Historical Financial Statement Information to Separate Winners from Losers." Journal of Accounting Research, Vol. 38 Supplement: 1-41.

18. Skinner, Douglas J. 1994. "Why Firms Voluntarily Disclose Bad News." Journal of Accounting Research, Vol. 32, No. 1: 38-60.

\section{NOTES}

